pressure of the cell sap of Pilobolus is about $5 \cdot 5$, and he and T. C. Vanterpool reported that the so-called secondary conidia of the stinking smut fungus are true basidiospores. Dr. W. P. Thompson and collaborators gave a series of important papers dealing with the cytological cause and genetical effects of shrivelled endosperm in species-crosses of wheat, chromosome homologues in wheat and Aigilops, and chromosome differences in the vulgare wheats.

Other papers included craniometrical studies involving a number of new cranial indices (John Cameron), data concerning the numbers of molecules in the red-blood corpuscle (A. T. Cameron), study of prostate extracts with an adrenine-like action (J. B.
Collip), new evidence as to the true location of the respiratory centre, in disagreement with Lumsden's work (V. E. Henderson and T. A. Sweet), forelimb reflexes and their reciprocal muscular co-ordination (F. R. Miller), and the temperature limits of Grylloblatta (E. M. Walker). Dr. F. C. Harrison gave an important communication on the cause of discoloration of the bellies of Pacific Coast halibut, which he showed to be due to $P s$. fluorescens introduced by the ice used for packing the fish.

The meeting in 1930 will be held at McGill University, Montreal, under the presidency of Prof. A. S. Eve, Macdonald professor of physics in MeGill University.

\title{
Afforestation of Peat Lands in Sweden.
}

\section{$\mathrm{F}^{\circ}$}

OR a considerable period the Swedish Institute of Experimental Forestry has devoted extensive research to the problem of draining peat and marshy lands for afforestation purposes. Numerous investigations have been carried out with the view of gaining increased knowledge of the various properties of peat soil types and their suitability to draining by the ordinary forest method of open ditches. The importance of this study to Sweden will be evident when it is remembered that half the total exports consist of the produce from her forests, and that it is estimated that there are some $3,000,000$ acres of this type of land which can be made suitable for the growth of trees.

The methods of inquiry projected have been on several different lines. Earlier types of drainage ditches have been studied with their results; and special drainage operations have been undertaken on varying types of marsh and peat lands, which have been thoroughly investigated geologically, hydrologically, and biologically. Laboratory investigations have also been undertaken into the physical and chemical properties of various kinds of peat. The careful work thus carried out over a series of years may have some considerable importance to Great Britain, in parts of which extensive tracts of peat lands exist.

The results of the Swedish investigations have been published in the Reports of the Swedish Institute of Experimental Forestry, No. 24 (1927-28), the paper by Carl Malmström being entitled "Våra Torvmarker ur Skogsdikningssynpunkt". The author states that his paper gives a general review of the results that have been obtained in regard to the suitability of different types of peat ground for draining, both as to the possibilities of draining it with advantage and the qualities of the timber to be obtained from it after the operations.

Investigations into the possibility of extending the area of forests in Sweden were begun in the middle of last century, coinciding with the commencement of Sweden's exploitation of the forests to capture a share of the European trade in soft woods which were replacing the broad-leaved timbers. Amongst others, C. G. Indebetow, T. L. Bohnstedt, and Bishop C. A. Agardh advocated ditching as the method by which poor unproductive peat lands might be afforested; the latter stating that the removal of excess water by this means would also improve the local climate.

Towards the end of the nineteenth century, a further motive for carrying out this type of drainage operation arose, it being suggested that such drainage would prevent peat-formations from spreading over still healthy forest land. At the beginning of the present century, therefore, the inquiry was con- sidered from the twofold point of view of improving boggy land and as a protective measure, in many cases considered essential to obtain enduring results from good forest lands. The protective idea originated in northern Sweden, where there are extensive areas of poor forest growth where the soil is covered entirely or in patches with carpets of Sphag. num and Polytrichum commune. The fear of the spread of this type of formation came to be applied to parts of southern and central Sweden, and particularly to areas, as for example in western Småland and north-west Dalecarlia, where widespread complexes of moss are to be found. The investigations by the Institute of Experimental Forestry so far carried out, in this latter direction, are said to have produced " incontestable evidence that at the present time the danger of any general process of rapid bog-formation affecting the forests of Sweden is slight". The caution is added, however, that " this does not mean that locally, e.g. in the case of neglecting to clean out ditches, the confluence of streams, deforestation, forest fires, etc., processes of bog-formation cannot take place comparatively rapidly".

The business of improving poor peaty and marshy land in Sweden by laying out a series of ditches has now many enthusiastic adherents, both government and private land owners, and the author deems it necessary, owing to failures which have been experienced, to voice some warnings. Difficulties, he says, very similar to those experienced by farmers when they have sought to utilise certain types of peat land for cultivation purposes, have been experienced by foresters. Just as the farmer learnt by sad experience that it is wasted labour to try to cultivate economically, for example, mosses with large superficial layers of entirely undisintegrated Sphagnum peat, the forester now realises that certain types of peat soil react extremely slowly, if at all, after draining; whilst others soon after draining show a considerable and enduring improvement in the forest growth.

On the subject of the amount of water to be drained off, it has been shown that varying types of peat soils display remarkable differences in this respect. Investigation work has accordingly been concentrated on the degree of moisture and the biological properties of peat ground and also on its productive capacity after draining from the forestry point of view, and it is hoped by this means to arrive at an even greater certainty in the selection of areas to be drained and also on the correct method of laying out the system of drains for particular types of peat and marshy areas. The necessity for protective drainage schemes having, as explained above, been proved to be of local importance only, the investigation work is now

No. 3116, VoL. 124] 
concentrated on drainage for afforestation purposes and the work is confined to those classes of peat soil which have so far been shown to respond and to show, without too expensive and elaborate a drainage scheme, a considerable and lasting improvement within a short time. "Peat ground", says the author, "that is hard to drain off and poor in quality, or in which the reaction takes place too slowly, must obviously, according to the present views, be entirely abandoned. It is clear, however, that in the event of drainage operations becoming cheaper or forest products increasing in value, or should it be possible to reduce the administrative and transport costs of lumbering, the poorer types of peat ground may be advantageously treated." The author then deals at length with the drainage possibilities of peat ground, its qualifications for producing timber after draining, and finally considers the conditions governing the most important types of peat land where draining is to be undertaken.

On the subject of classifying peat ground for forestry purposes, Mr. Malmström says that experience has shown that it is not possible unreservedly to use the old schemes of differentiating the types, which were set up on the basis of the topography, the plant associations, or the evolutionary history of the peat ground. Some of these may usually be better than others, but exceptions to this rule have been found. Unfortunately, there is at present no possibility of forming any such judgment in a simple stereotyped way, such as with the guidance of a certain definitely determinable property in the virgin peat soil. The peat's power to react after draining is determined by many contributory factors ; as, for example, the composition of the peat, degree of disintegration and porosity, fungal and bacterial life, climate, and, above all, the power of the peat to absorb and retain water.

There is, however, an empirical and, for practical purposes, satisfactory method of judging in advance the qualifications of peat ground for producing timber after draining. This consists in studying the vegetation produced on the peat in its natural state and taking special note of the presence or absence of certain plants. Luxuriant vegetation (especially dwarf shrubs and bushes) often provides a good indication as to the biological conditions of the ground ; that is, of those intrinsic properties which, after draining, largely determine the success of forest production, although they are not apparent from direct observation of the plant community. The species of trees and certain bushes and shrubs are particularly helpful. Alder (A. glutinosa and incana) is a good indication on several types of peat; and spruce and birch may also serve as a sign, especially if the trees have a healthy and normal appearance. The spruce by itself is more uncertain, and where it is stunted and knotty usually indicates a soil unsuitable for drainage schemes. Willows, juniper, and dwarf birch (B. nana), if tall and flourishing, indicate peat soils worth draining. When the areas are treeless, experience has shown that the presence of certain grasses, sedges, and herbs will furnish an indication of the peat's disintegration and porosity, especially in south and central Sweden. Plants of this kind are high sedges (Carices) and various types of cotton grass (Eriophorum): when these are present and the peat is fairly well disintegrated, the area is suitable, whilst the reverse is the case with areas of more or less undisintegrated peat covered with cotton grass and Scirpus coespitosus.

Mr. Malmström's paper may be regarded as a valuable aid in a most important and difficult problem in afforestation in which forest officers in several parts of Europe are vitally interested, and it will well repay a careful study.

No. 3116, VoL. 124]

\section{University and Educational Intelligence.}

Birmingham.- The Walter Myers travelling studentship for research in any branch of pathology approved by the selection committee is being offered. The value is $£ 300$. The holder of the studentship will be required to devote his or her whole time to research. Applications must reach the Dean by at latest Sept. 2 .

EdinbURGH.-At the summer Graduation Ceremonial the honorary degree of Doctor of Laws was conferred upon Mr. J. B. Clark, formerly Headmaster of George Heriot's School, Edinburgh ; Prof. E. S. Goodrich, Linacre professor of zoology and comparative anatomy, University of Oxford; Prof. A. V. Hill, Foulerton researeh professor of the Royal Society Prof. C. E. Inglis, professor of mechanism and applied mechanics, University of Cambridge; Dr. A. P. Laurie, formerly principal of the Heriot-Watt College, Edinburgh ; Sir James Walker, professor-emeritus of chemistry; and the Right Hon. Lord Woolavington of Lavington. The degree of Doctor of Science was conferred on Mr. John Mackie, for a thesis entitled "An Inquiry into the Tetrad-difference Method of Testing the Two-factor Theory of Intelligence" ; Dr. Christina C. Miller, for a thesis entitled "The Slow Oxidation of Phosphorus"; Dr. Frederick Walker, for a thesis entitled "The Geology of the Shiant Isles" ; and Mr. John M. Whittaker, for a thesis entitled " On the Stieltjes Integral and on the Expansions of Interpolation Theory"

The Court has appointed Mr. C. B. Williams to be Steven lecturer in agricultural and forest zoology in succession to Dr. Stewart MacDougall.

MANCHESTER.-Invitations are invited for the Amy Henrietta Worswick Fellowship, value $£ 150$, for the investigation of the causes and treatment of rheumatoid arthritis. Applications must reach the Registrar by Oct. 15.

St. Andrews.-By a recent ordinance a chair of botany has been established in the University, placing under the new professor the Departments of Botany in the United College, St. Andrews, and in University College, Dundee. The lectureship in botany in Dundee and the assistant lectureship in the United College as presently existing are continued under the new arrangement, and it has been agreed that the first appointment to the new chair should be offered to Mr. R. A. Robertson, who was appointed lecturer in botany in the United College, St. Andrews, in 1891, and reader in botany in 1915 . Mr. Robertson has accepted the offer and has been appointed as from Oct. 1 next.

The Trustees of the Beit Fellowships for Scientific Research have made the following elections to fellowships tenable at the Imperial College of Science and Technology for two years $1929-30$ and $1930-31$, of the value of $£ 250$ per annum: Mr. N. S. Grace, University of Saskatchewan, Saskatoon, Canada, for physical chemistry; Mr. J. J. Green, Imperial College, for an investigation of the nature and cause of the breakdown in agreement between the theoretical and observed viscous fluid motion round a circular cylinder; Dr. F. K. V. Koch, Imperial College and Universities of Dresden and Munich, for the continuation of an inquiry into the solution tension of silver in solvents other than water, and the connexion between solution tension and complex formation. The Trustees have confirmed the awards for a second year to Mr. A. A. Fitch (geology); Mr.J.M. Frankland (metallurgy); Mr. E. C. S. Megaw (electrical engineering). 